\title{
The Regulation Reform for New Zealand Financial Advisers
}

\author{
Mingwei Xu \\ Liaoning University \\ 66 Congshan Zhong Lu Road, Shenyang, Huanggu District, China \\ E-mail: xumw128@126.com \\ Roger Su \\ Auckland University of Technology, New Zealand \\ Private Bag 92006, Auckland, New Zealand \\ Tel: 64-9-921-9999-5058Ｅ-mail: roger.su@aut.ac.nz \\ Amitabh S. Dutta \\ Florida Institute of Technology, USA \\ 150 W. University Avenue, Melbourne, FL 32901, USA \\ E-mail: adutta@fit.edu
}

Received: March 30, 2011 Accepted: April 18, 2011 doi:10.5539/ibr.v4n3p127

\begin{abstract}
The recent global financial crisis has highlighted the need to re-examine the connections between financial markets, institutions and their regulations. The New Zealand Government had passed the Financial Service Providers (Registration and Dispute Resolution) Act and the Financial Advisers Act into law in 2008. Under the new legislation regime, only AFAs (Authorised Financial Advisers) can provide wide range financial service after $1^{\text {st }}$ July 2011 . This article will go through the process of change and the details of new legislation of AFA; and provide the picture of New Zealand financial adviser regulation reform.
\end{abstract}

Keywords: Authorised Financial Adviser, AFA, Regulation, Financial Service Providers Act, Financial Advisers Act

\section{Introduction}

Investment advisers in the US are regulated under the Investment Advisers Act 1940 (Laby, 2010) while Australian financial advisers have to hold a license since 2005 (Tuch, 2006). Prior to 2008, the only legislation that New Zealand financial advisers have to obligate is the Investment Adviser (Disclosure) Act 1996 (IAC). Under IAC 1996, there were two forms of disclosure: one is mandatory disclosure which includes information about any convictions and advisers have for dishonesty or bankruptcy during the preceding five years, and the procedures of the broker relating to the receipt or disbursement of money or property; the other is to provide financial advisers' qualifications and experience and matters that could indicate conflicts of interest (Hosking, 2002).

Financial regulation in New Zealand is at a critical juncture; the current global crisis and New Zealand finance company failures push New Zealand government to do something to promote sound and efficient delivery of financial advice, and to encourage public confidence in the professionalism and integrity of financial advisers.

In 2008, the Financial Service Providers (Registration and Dispute Resolution) Act and the Financial Advisers Act were passed into law. Under the FSPA 2008, any individuals and entities in the business of providing financial services have to register with the New Zealand Companies Office. Applicants also have to pass a criminal conviction background check and join an approved consumer dispute resolution scheme. To provide advice on high risk, long term investment products or financial planning service, financial advisers not only have to be registered with the Companies Office also separately "authorised" by the Securities Commission under the Financial Advisers Act 2008. Full implementation of both Acts is scheduled to be completed by December 2010 (New Zealand Companies Office, 2010).

This financial service regulation reform aim to achieve the following outcomes (Ministry of Economic Development, 2009):

1. A sound and efficient financial sector;

2. Investment that encourages growth and innovation; 


\section{An environment that facilitates wealth accumulation; and}

\section{Confidence in the sector to encourage participation by consumers and market participants.}

The remaining part of this article is structured as follows. The next section provides the background of Financial Adviser Act 2008 and Financial Service Providers Act 2008. Section 3 outlines the coming AFA implementation. Section 4 explores relevant topics arising from the new legislation; and, a final section concludes and summarizes the article.

\section{Background}

Many of New Zealanders are currently financial stressed by the global financial crisis (Guha, 2010) which began from the bankruptcy of Lehman Brothers in September 2008. When most people believe this crisis began from the origins of the panic of 2007 -subprime crisis (Bruner, 2009); Su (2009) points out that New Zealand financial crisis can be said to have begun in May of 2006 when National Finance went to receivership. Since then, further forty-five finance companies failed, the total amount they owe investors is nearly $\$ 4.5$ billion up to July 2008 ; the owing amount increased to $\$ 6$ billion in March 2009 (Beatson, 2009); Table 1 summarizes major failure finance companies and mutual funds between 2006 and 2008.

More than 100,000 households suffer the loss in those New Zealand's own home-grown finance sector crisis (Beatson, 2009). Investors and the public believe poor corporate governance and lack of regulation were the main cause of the finance company sector collapse (Parker, 2010). New Zealand Securities Commission should keep under review the law relating to bodies corporate, securities, financial advisers, and to recommend to the Minister any changes thereto that it considers necessary (Beatson, 2009). By the end of 2008, after most of 46 troubled New Zealand finance companies had collapsed, the public believed that New Zealand Securities Commission must take some blame for these debacles particularly in the unclear prospectuses or investment statements and financial advisor regulations (Beatson, 2009).

Investors also questioned whether New Zealand investment advisers are subject to professional requirements which come with being authorised: competency qualifications, conduct rules (directed to both ethics and client service) and a commitment to keep up-to-date with industry knowledge (Mayhew, 2010). Some investors claim that their advisers failed to give an adequate explanation of investment products and the risks attached to them (Chaplin, 2008); public anxiety in the wake of continuous financial product failures has pressured the government to amend the Financial Advisers Bill.

The case for stronger regulation of the finance sector has been strengthened by the collapse of numerous New Zealand finance companies and the current global financial crisis. At the end of 2008, New Zealand cabinet passed the Financial Advisers Act and the Financial Service Providers Act into law. The New Zealand Commerce Minister Simon Power said (2010) "both financial advisers Act 2008 and the Financial Service Providers Act 2008 are important measures to rebuild mum and dad investor confidence in the finance sector which has been shaken by finance company failures and the global recession." The objective of this paper is to provide the details of AFA implementation and debate issues for AFA as well.

\section{AFA Implementation}

From the Financial Advisers Act 2008, financial adviser service is defined as "a person performs a financial adviser service if, in the course of business, a) gives financial advice; or b) makes an investment transaction; or c) provides a financial planning service." In other words, when a person makes a recommendation or gives an opinion or guidance in relation to acquiring or disposing of a financial product, this person gives financial advice.

All New Zealand financial advisers are categorized into three types: a), a authorized financial adviser (who is authorized and registered); b) a financial adviser who is registered but who is not authorized; and c) a financial adviser who is neither registered nor authorized but who is an employee or agent of a qualifying financial entity (QFE) (the Financial Advisers Act 2008). "A QFE is a company approved by the Securities Commission to take responsibility for the advice provided by its employees and contractors on a limited range of products, instead of those people each requiring their own licence" ( New Zealand Parliament, 2010).

Table 2 at Appendix has provided a clear picture of whether a financial adviser needs to be registered or authorized. Therefore, a person (in New Zealand) wants to be a financial adviser in the new regime, he/she will need to be authorized by the Securities Commission, as well as registered by the Companies Office, unless he/she only provides a relatively narrow range of products or service.

Under the new regime, an authorized financial adviser can not only provides a disclosure, he/she also need to provide more to meet the Securities Commission requirement. As an AFA, he/she must have good character; and capacity of knowledge and ability to help their clients to meet their financial goals with risk tolerance level (which 
means a potential AFA must complete necessary study courses before authorization); he/she also has to provide a snapshot of how AFA operate which explains the systems and procedures AFA has to ensure their conducts their business in a professional way; once all required documents are ready, he/she can register and apply for authorization. In Appendix section, we provide more details of the pathway to becoming an AFA.

\section{Relevant topics arising from the new legislation}

White (2010) believes the regulatory changes can be part of the relationship between New Zealand and Australia which does have a licensing regime of financial advisory industry. Also, New Zealand competency requirements will meet Australian financial adviser competency which may encourage financial advisers working cross Tasman (White, 2010).

New Zealand investors' confidence has increased when financial advisory industry is heading with regulation. "People have a better perception of financial advisers now that it is becoming a regulated profession with advisers working towards competence and authorisation" (White, 2010). Two-thirds of financial advisers believe that regulation provides an opportunity to grow their business according to the increase in trust and confidence of investors (White, 2010a).

Current legislations and proposals will create an incentive for independent financial advisers to join a QFE to avoid their obligation to train and to avoid the cost of authorisation (McBeth, 2010); which may make AFAs more competitive when they offer wider scope of service to clients. But, under the new regulatory regime, AFAs won't able to operate through limited liability companies and will become personally liable for any financial advice they give (Williams, 2010).

Under the new regulatory regime, financial advice has to be provided by individuals in New Zealand, which will damage New Zealand's international reputation by preventing large corporate entities from providing financial advice here (McBeth, 2010a). Furthermore, the legislation aims to regulate financial advisers and financial planners but it has gone far broader that, and applies to anyone giving financial advice such as advice of property buying provided by a builder or architect. "We don't expect builders or architects sitting financial adviser exam" (Williams, 2010).

Argument also from some insurance advisers that they don't believe they should be authorized. They believe that even them analysis clients' situation and give recommendation; they don't believe their clients typically have goals for their death or disability (Lindsay, 2010). In June 2010, the Commerce Select Committee made public proposed changes on the definition of "Financial Planning Service" to a new concept of "Investment Planning Service" appearing to remove the requirement for insurance advisers to become AFAs (Nicoll, 2010). Because this legislation is new coming, we have not head any academic arguments in the markets, only some debate above issued from professional industry.

\section{Conclusion}

New Zealand cabinet passed the Financial Advisers Act 2008(FAA) and the Financial Service Providers Act 2008(FSPA) into law in 2008; the Code of Professional Conduct for Authorised Financial Advisers had been approved on $7^{\text {th }}$ May 2010; the FSPA will be fully in forced since $1^{\text {st }}$ December 2010 and the FAA 2008 will be fully in forced from $1^{\text {st }}$ July 2011.

The new legislation regime may help to increase the confidence of investors and build up the credit trust for New Zealand financial advisers which help financial service industry to grow, although the legislation regime still needs to be improved.

Scott (2008) cited Simon Power, New Zealand National Party Spokesman, "Laws to regulate financial advisers cannot protect investors against all forms of loss; legislators should take care not to over-regulate financial advisers".

The New Zealand Government is now aiming to finalise the regulations for the regime, approve the Code of Conduct, and make sure that all systems and processes are in place to ensure that advisers and other financial service providers can begin operating under the new regulatory framework (Nicoll, 2010). As a new legislation, FAA2008 and FSPA2008 would give investors more confidence; however, it is still need to be improved to meet the future changing economic status.

\section{References}

Beatson, D. (2009). Finance failures -our $\$ 6$ billion blame game. Retrieved May 20, 2010, from http://pundit.co.nz/content 
Bruner, R. (2009). The dynamics of a financial dislocation: The panic of 1907 and the Subprime Crisis. Working paper, Insights into the Global Financial Crisis. Research Foundation of CFA Institute.

Chaplin, D. (2008). Adviser amendments to rebuild investor confidence, Dalziel says. Retrieved May 20, 2010, from http://www.goodreturns.co.nz/article/976493970/adviser-amendments-to-rebuild-investor-confidence-dalziel-says.ht $\mathrm{ml}$

Code Committee. (2010). Code of professional conduct for Authorised Financial Advisers. Code Committee, New Zealand.

Financial Advisers Act. (2008). Ministry of Economic Department, New Zealand.

Guha, G. (2010). Most Kiwis undergo financial crisis. Retrieved May 20, 2010, from http://topnews.net.nz/content

Hosking, R. (2002). Financial advisers regime to be strengthened.( 2004, December 12). Good Returns. Retrieved May 20, 2010, from http://goodreturns.co.nz

Laby, A. (2010). Reforming the regulation of broker-dealers and investment advisers. The Business Lawyer, Vol.65, pp.395-440.

Lindsay, G. (2010). Why I don't want to be an AFA. Asset, Vol. 9 (4), pp. 11.

Mayhew, D. (2010). Are you an AFA? New Zealand Asset, vol. 9 (3), pp. 12-13.

New Zealand Companies Office, (2010). Introducing financial service providers. Retrieved May 21, 2010, from http://www.companies.govt.nz/cms/other-registered-ent

McBeth, P. (2010). Power plugs holes in financial adviser legislation. Good Returns. Retrieved June 10, 2010, from http://www.goodreturns.co.nz

McBeth, P. (2010a). Financial adviser legislation threatens NZ's reputation: Chapman Tripp. Good Returns. Retrieved June 10, 2010, from http://www.goodreturns.co.nz

NZICA (2010). Advice for financial advisers. The Chartered Accountants Journal, Vol. 89 (3), pp.22-23.

New Zealand Parliament ( 2010). Financial Service Providers (Pre-Implementation Adjustments) Bill 2009. New Zealand Bill Digests No. 1740. Retrieved May 20, 2010, from http://www.parliament.nz

Nicoll, J. (2010). Regulation Update -15 June 2010. ING Life New Zealand Limited, Auckland, New Zealand.

Parker, T. (2010). Weak controls to blame for finance fiasco: study. New Zealand Herald, retrieved April 15, 2010, from http://www.nzherald.co.nz/business/news/article.cfm?c_id=3\&objective=10637998\&pn

Power, S. (2010). Cabinet makes key decision on finance sector laws. News Release, 26 February, 2010. The Minister of Commerce of New Zealand.

$\mathrm{Su}$, R. (2009). The motivation and investment preferences of Chinese investors who migrate to New Zealand. PhD thesis. Auckland University of Technology, New Zealand.

Ministry of Economic Development (2009). Implementation of the Financial Advisers Act and Financial Service $\begin{array}{llllll}\text { Providers Act. } & \text { Retrieved } & \text { May } & 21, & \text { 2010, } & \text { from }\end{array}$ http://www.med.govt.nz/templates/MultipageDocumentTOC__41042.aspx\#A1

Scott, M. (2008). Do not over-regulate advisers: Power. Good Returns. Retireved May 20, 2010, from http://www.goodreturns.co.nz/article/976494300

Securities Commission (2010). AFA Adviser Business Statement Guide. Regulatory Guide: FAA 02.1. New Zealand.

Tuch, A. (2006). Obligations of financial advisers in change-of-control transactions: Fiduciary and other questions. CSLJ, Vol. 24, pp. 488-521.

White, J. (2010). Code changes rules around education. (2010, March 31). Good Returns. Retrieved May 20, 2010, from http://www.goodreturns.co.nz

White, J. (2010a). Confidence in regulation helping business to grow. (2010, April 15), Good Returns. Retrieved May 20, 2010, from http://www.goodreturns.co.nz

Williams, T. (2010). Advisers to become personally liable for advice. (2009, August 3). Good Returns. Retrieved May 20, 2010, from http://www.goodreturns.co.nz

\section{Appendix}


Table 1. The failure finance companies \& frozen mutual funds between 2006 and 2008

\begin{tabular}{|c|c|c|}
\hline Company or fund name & Collapse Time & $\begin{array}{l}\text { the amount owing to investors } \\
\$ \mathrm{~m}\end{array}$ \\
\hline National Finance & May-06 & 25.5 \\
\hline Provincial Finance & Jun-06 & 300 \\
\hline Western Bay Finance & Aug-06 & 48 \\
\hline Bridgecorp & Jul-07 & 500 \\
\hline Nathans Finance & Aug-07 & 166 \\
\hline Property Finance Securities & Feb-07 & 710 \\
\hline Five Star Finance & Aug-07 & 57.6 \\
\hline LDC Finance & Sep-07 & 19.3 \\
\hline Finance \& Investments & Sep-07 & 16 \\
\hline BDO Spicers & Oct-07 & 15 \\
\hline Beneficial Finance & Oct-07 & N/A \\
\hline Geneva Finance & Oct-07 & 138 \\
\hline Capital + Merchant & Nov-07 & 190 \\
\hline Numeria Finance & Dec-07 & 6.7 \\
\hline MFS Finance & Feb-08 & 335 \\
\hline MFS Boston & Feb-08 & 38.5 \\
\hline ING (Diversified Fund \& Regular Income Fund) & Mar-08 & 520 \\
\hline Lombard Finance & Apr-08 & 127 \\
\hline Kiwi Finance & Apr-08 & 2 \\
\hline Tower(Mortgage fund) & Apr-08 & 242 \\
\hline Fairview NZ & May-08 & 6.9 \\
\hline Belgrave Finance & May- 08 & 20 \\
\hline Dominion Finance & Jun- -08 & 276 \\
\hline St Laurence & Jun-08 & 240 \\
\hline Dorchester Finance & Jun- 08 & 168 \\
\hline Canterbury Mortgage Trust & Jul-08 & 250 \\
\hline Hanover Finance & Jul-08 & 554 \\
\hline NZ Guardian Trust & Jul-08 & 249 \\
\hline
\end{tabular}

(Source: designed for this research. May 2010).

Table 2. Requirement for Registration and /or Authorisation

\begin{tabular}{|c|c|c|c|}
\hline & FA is not in $\mathrm{A}$ QFE & \multicolumn{2}{|c|}{ FA is employed by / a nominated representative of a QFE } \\
\hline $\begin{array}{l}\text { Financial advises ONLY on Category } 2 \\
\text { products** }\end{array}$ & Registered only & Not & required \\
\hline $\begin{array}{l}\text { Financial advisers on Category } 1 \text { products } \\
\text { (Not providing financial planning service)* }\end{array}$ & $\begin{array}{l}\text { Registered and } \\
\text { Authorized }\end{array}$ & $\begin{array}{l}\text { Registered and } \\
\text { Authorized if advising on } \\
\text { third party products }\end{array}$ & $\begin{array}{l}\text { Not required if advising } \\
\text { ONLY on products issued } \\
\text { or "promoted" by the QFE }\end{array}$ \\
\hline $\begin{array}{l}\text { Financial advisers provide a financial planning } \\
\text { service }\end{array}$ & $\begin{array}{l}\text { Registered and } \\
\text { Authorized }\end{array}$ & Registered and Authorized & \\
\hline
\end{tabular}

(Source: designed for this research. June 2010).

* Category 1 product means -

a) A security (other than a security that is a category 2 product); or

b) Any estate or interest in land; or

c) A futures contract; or

d) Any other product specified by the regulations

** Category 2 product means -

a) A call debt security; or

b) A bank term deposit; or

c) An insurance product excluding a life insurance policy issued after 31 December 2008; or

d) A consumer credit contract; or

e) Any other product specified by the regulations.

(From: Financial Advisers Act 2008) 


\section{The pathway to becoming an AFA}

- Proof of good character

The candidate should provide two testimonials or character references; and declare any criminal convictions which will be checked with Ministry of Justice.

Step Two: Proof of competence

The FAA 2008 aims to "promote the sound and efficient delivery of financial advice, and to encourage public confidence in the professionalism and integrity of financial advisers" (the FAA 2008). To achieve this purpose, the FAA 2008 requires all authorized financial advisers comply with a Code providing minimum standards of professional conduct. The Code contains minimum standards of competence, knowledge and skills, of ethical behaviour, and of client care. The Code of professional conduct for Authorised Financial Advisers was approved by Code Committee on May 7, 2010.

"The Code is essentially a road code for financial advisers, you can't go on the road as an AFA unless you show you can understand the Code, the Act and the Consumer laws" (White, 2010). White(2010) points out that the Code Committee seek to ensure those qualifications would give consumers the confidence and trust to know they were of a level and content in line with the National Certificate in Financial Services ( Financial Advice) (Level 5). Some New Zealand institutes such as ETITO, Massey University and Adviser-Link have launched NCFS-5 course or equivalence.

The National Certificate in Financial Services (Financial Advice) (Level 5) comprises five unit standard sets:

A. Knowledge of the industry, financial markets, the advice process and products;

B. Knowledge of the Code and consumer protection laws;

C. Professional practice advice process and complying with legislation;

D. Investment specialist standards;

E. Insurance specialist standards or Residential property lending specialist standards.

The existing attained qualifications or designations held by financial advisers may be treated as having satisfied the requirements of the specified Unit Standards; financial advisers may apply for specified Unit Standards exemption (Code Committee, 2010).

- Developing Adviser Business Statement

As part of the authorization application process, AFAs must prepare an Adviser Business Statement - ABS. ABS is a snapshot of how AFAs operate. It explains the systems and procedures AFAs have to ensure their conducts their business in a professional way. ABS is a living document which is obliged to keep up to date so it reflects any changes in AFAs' business and any changes in the requirements inFAAs and the Code (Securities Commission, 2010).

The ABS consists of two parts:

One is to describe AFAs' business, which helps the Securities Commission to understand the business operated by AFAs;

Two is to explain the systems and procedures AFAs have in place to comply with:

- The Financial Advisers Act and its regulations

- The Code of Professional Conduct for Authorised Financial Advisers

- The terms and conditions of AFAs' authorisation.

AFAs don't need to attach their ABS to their application; however, it must be available for the Securities Commission to see on request -both before and after authorisation.

- Developing or revise disclosure statement in accordance with disclosure regulations

Under the Financial Advisers Act 2008 (the FAA 2008), a financial adviser must make disclosure to their client before providing a financial adviser service. The purpose of disclosure is to ensure that investors can make informed decisions about whether to use a financial adviser and whether to follow that financial adviser's advice.

Under the FAA 2008, an authorized financial adviser must disclose the information prescribed (in written) by regulations in any or all of the following matters:

a) Professional or business experience relevant to performance of a financial adviser service; 
b) Disciplinary proceedings;

c) Criminal convictions;

d) Adverse findings by a court or the Commission;

e) Fees;

f) Bankruptcy or other insolvency proceedings;

g) Material interests, relationships, or associations;

h) Remuneration;

i) Financial products in relation to which a financial adviser service is performed;

j) Dispute resolution arrangements;

k) Procedures for handling a client's money or other property

l) Location of business premises; and

m) Matters required to be disclosed by the financial adviser's term and conditions of authorisation.

The previous disclosure does not discharge a person's disclosure obligation if the previous disclosure is out of date when the financial adviser service is performed.

- Registering and applying for authorization

After July 2010, New Zealand AFA candidates may start to apply for registration and authorisation in the same seamless process at Financial Service Provider Register (FSPR) online: www.fspr.govt.nz (this website will open on 1 July 2010). The details of authorisation process are shown below on Chart 1 .

Chart 1 - Applied for Registration and Authorisation
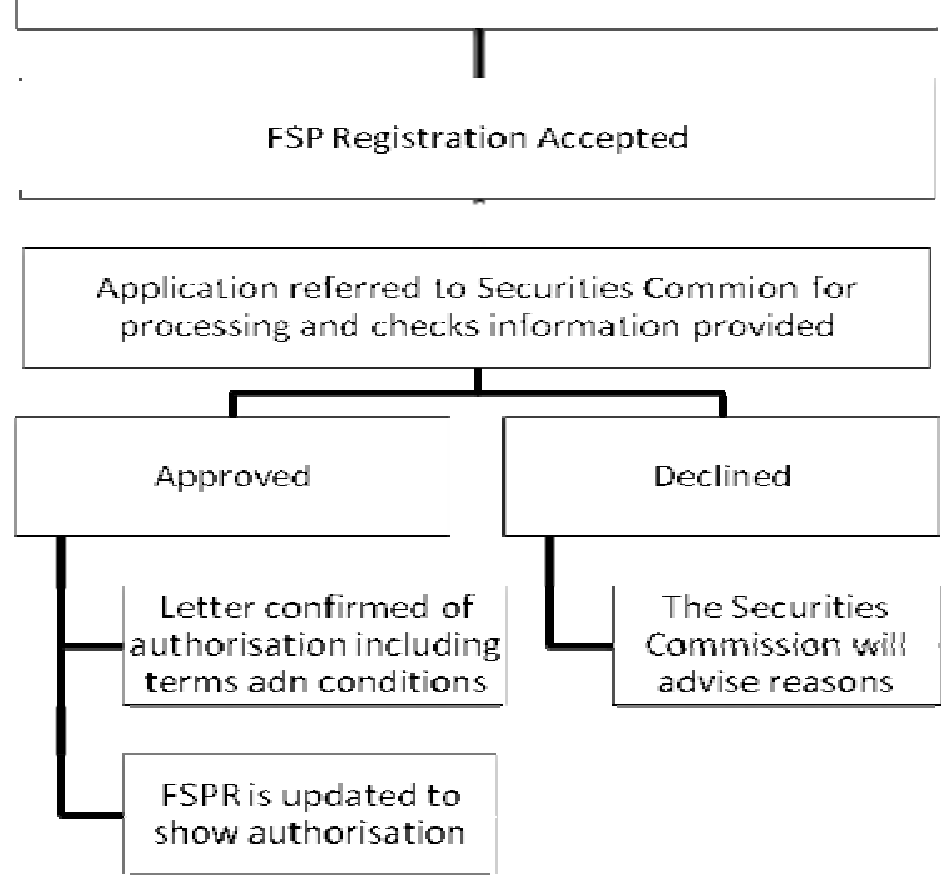

( Source: Designed for this research. June 2010) 
If a company applies QFE status, the application process is shown as Chart 2 below:

Chart 2 - OFE status
application

Application Subnits ABS to the Secuirities Commion

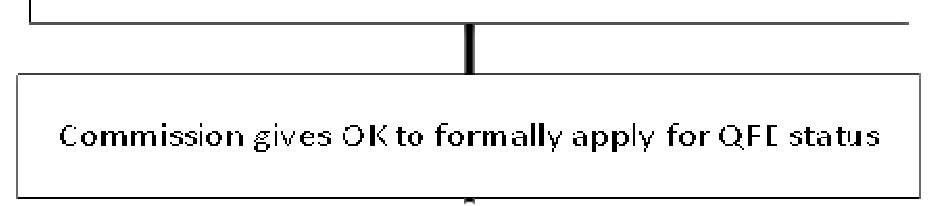

Apply for Registration and QFE Status on the FSPR

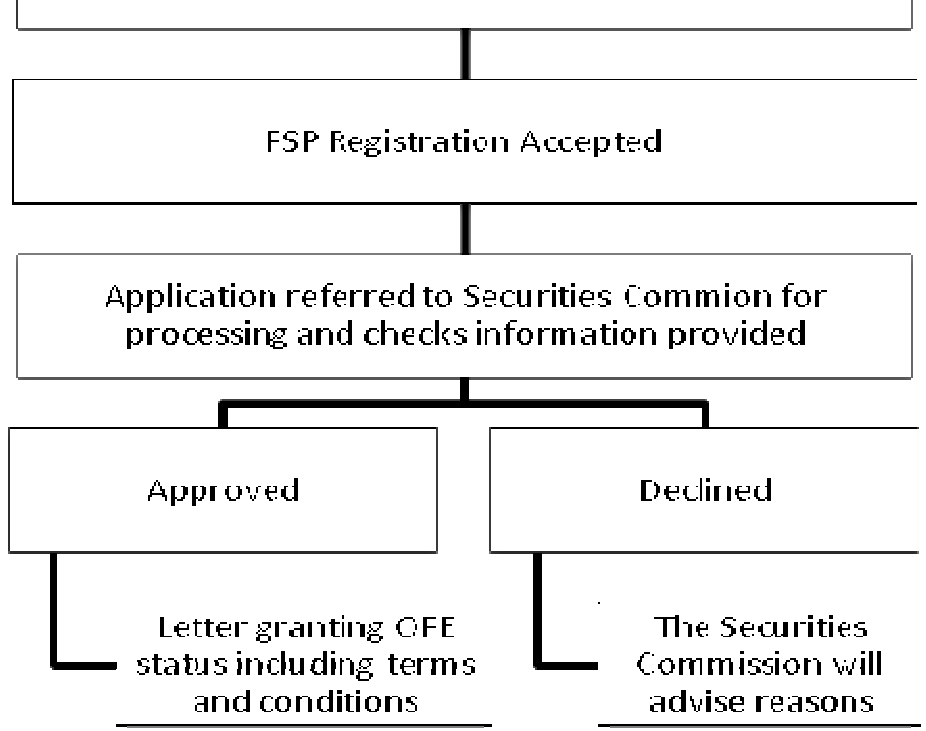

(Source: Designed for this research, June 2010)

The Securities Commission has provided the timeline for all AFAs:

1 July 2010 - registraion and application for authorisation open at www.fspr.govt.nz .

1 December 2010 - Financial Service Provider Act 2008 will be fully in force and application for authorisation to be received. All financial advisers, whether authorised or not, must comply with the care, diligence and skill provisions of the Financial Advisers Act 2008 from this date. Once authorised, a financial adviser can call himself/herself an AFA.

1 July 2011 - Financial Advisers Act 2008 will be fully in force. Only AFAs can provide a financial plnning service or advice on category 1 products, unless covered by a QFE. 